\title{
A gender approach to understanding the differentiated impact of barriers to adaptation: responses to climate change in rural Ethiopia
}

\author{
Azeb Assefa Mersha ${ }^{1,2,3} \cdot$ Frank Van Laerhoven ${ }^{1}$
}

Received: 22 May 2015/ Accepted: 21 December 2015/Published online: 7 January 2016

(C) The Author(s) 2016. This article is published with open access at Springerlink.com

\begin{abstract}
While adaptation has received a fair amount of attention in the climate change debate, barriers to adaptation are the focus of a more specific, recent discussion. In this discussion, such barriers are generally treated as having a uniform, negative impact on all actors. However, we argue that the precise nature and impact of such barriers on different actors has so far been largely overlooked. Our study of two drought-prone communities in rural Ethiopia sets out to examine how female- and male-headed households adapt to climate change, particularly focusing on how a variety of barriers influence the choice of adaptation measures to varying extents. To this purpose, we built a conceptual framework based on the Sustainable Livelihood Approach. Data were collected using semi-structured interviews and focus group discussions with male- and female-headed households, community leaders and local extension workers. Our findings suggest that gender-based differences in the choice of adaptation measures at the household level are driven by cultural, social, financial and institutional barriers. Barriers to adaptation-particularly when interacting-have a differentiated impact upon
\end{abstract}

Editor: Jamie Pittock.

Azeb Assefa Mersha

a.assefamerha@uu.nl

Frank Van Laerhoven

f.s.j.vanlaerhoven@uu.nl

1 Copernicus Institute of Sustainable Development, Utrecht University, Heidelberglaan 2, 3584 CS Utrecht, The Netherlands

2 Tilburg University, Heidelberglaan 2, 3584 CS Utrecht, The Netherlands

3 Ethiopian Civil Service University, Addis Ababa, Ethiopia different actors. This outcome hints at the need for donors and policymakers to develop intervention strategies that are sensitive to this fact.

Keywords Adaptation - Barriers - Climate change Gender · Sustainable livelihood approach · Ethiopia

\section{Introduction}

In recognition of the inevitable impacts of climate change, attention to responses to these impacts by means of adaptation has been growing in recent years (Adger et al. 2007). Adaptation refers to the process of adjustment to actual or expected change in climate and its effects, aiming to moderate harm or to exploit beneficial opportunities in human systems (IPCC 2014b). Adaptation is closely linked with adaptive capacity. Adaptive capacity is defined as 'the ability of systems, institutions, humans, and other organisms to adjust to potential damage, to take advantage of opportunities, or to respond to consequences' (IPCC 2014b, p 1758). Adger et al. (2005) indicate that adaptation comprises both building adaptive capacity and implementing adaptation decisions.

Recently, the debate on adaptation has been expanding and now includes a particular focus on barriers to adaptation (Biesbroek et al. 2013) which are defined as 'factors that make it harder to plan and implement adaptation action' (IPCC 2014b, p 1758). Bryan et al. (2013) find that in Kenya, barriers that prevent households from adapting to climate change include a lack of means to invest in measures that go beyond marginal changes in planting decisions. Deressa et al. (2009) show how the range of barriers to adaptation includes education, age, wealth of the household head, access to extension and credit, and gender. 
The conclusions that Hassan and Nhemachena (2008) derive from their study of 11 African countries hint at partly similar barriers. In particular, they stress that access to markets, extension and credit services, technology and farm assets (labour, land and capital) are critical in helping African farmers adapt to climate change. A study of 160 households in the Babilie district of Eastern Ethiopia carried out by Tazeze et al. (2012) adds family size, livestock ownership, income from farm and non-farm activities to the factors highlighted above. In the analysis of a study conducted by Nabikolo et al. (2012), explicit attention is given to the role of gender, operationalised by looking at male- and female-headed households in Uganda, respectively. They test and corroborate the hypothesis that there is a gender dimension to the choice of a climate change adaptation strategies. Various literatures have identified different barriers to adaptation to climate change and shown them to be context-specific and varying both across time and space (Adger et al. 2009; Biesbroek et al. 2013).

We are now beginning to understand the types of barriers that affect the choices of farmers who are confronted by climate change. However, rather than perceiving gender as a barrier in and by itself, we are interested in getting to understand how and why barriers may be affecting maleand female-headed households differently. We build on and add to the important insights gained so far, by initiating the development of a unifying framework that, through a more standardised approach, would allow for an increased comparability of results.

The fourth assessment report of the IPCC denoted a lack of attention in the literature to social and cultural barriers to adaptation (Adger et al. 2007). Studies now begin to focus not only on social and cultural barriers but also on political, institutional and cognitive barriers to adaptation experienced by individuals, groups and organisations (Adger et al. 2009; Biesbroek et al. 2013). The fifth assessment report of the IPCC listed eight distinct types of barriers: physical; biological; economic; financial; human resource; social and cultural; and governance and institutional barriers, and barriers related to knowledge, awareness and technology, respectively (IPCC 2014a).

While expanding scholarly work recognises the decisive role that different barriers can play in processes of adaptation to climate change, the precise nature and impact of the different categories of barriers, and the interconnectedness between them, remains elusive. Overall, most literatures conceive of 'barriers' as having a linear, generic, and overall negative impact on people's ability to adapt adequately (Biesbroek et al. 2013). However, we feel that insufficient attention has been given to the fact that barriers-especially when combined-have a differentiated impact on different actors, in determining whether or how they can or will adapt to climate change. For instance, cultural barriers combined with social barriers may restrict the adaptation choices of (certain) women, while simultaneously facilitating adequate adaptation by (certain) men. Therefore, this study explores how differentiation in terms of the impact of barriers pans out on the ground. We take a gender perspective when looking at the adaptation measures of male- and female-headed households, respectively, in drought-prone rural areas of Ethiopia. We assume that as a vital relational concept in social reality, the concept of gender helps us to uncover the connections between different barriers and reveal how they may have different effects on female and male household heads' adaptation choices and decisions and their impact and effectiveness. According to MacGregor (2010, p 228), some of the existing literatures dealing with the gender-climate change nexus still continue to focus on 'women' rather than on 'gender'. This focus renders women disconnected from a gendered socio-economic, cultural and institutional reality by means of which their marginalisation is arguably constructed (Bretherton 1998). In line with this argument, and taking gender as our entry point, our study aims to answer two research questions. (1) How do male- and femaleheaded households adapt to climate change-in particular-to drought? And, (2) how do various types of-interconnected-barriers to adaptation influence their respective adaptation choices?

\section{A conceptual framework: the sustainable livelihood approach (SLA)}

Perceiving barriers to adaptation as operating in an interdependent manner helps to craft strategies to overcome them effectively (Biesbroek et al. 2013). Doing so requires a comprehensive framework. According to the framework proposed by Behrman et al. (2014), climate signals affect the vulnerability context (defined by user characteristics, biophysical characteristics, institutional arrangements, and information and technology), which in turns influences the adaptation arena (where actors with varying levels of decision-making power and resources interact). Well-being outcomes (i.e. livelihood security and empowerment) are both the result of what happens in the adaptation arena and the cause of subsequent changes to the vulnerability context. This framework partly satisfies our wish to analyse how various types of-interconnected-barriers to adaptation influence the respective adaptation choices of male and female household heads, respectively. What we borrow from the Behrman et al. framework is (1) the operationalisation of outcomes in terms of livelihoods; (2) the notion that adaptation is something that concerns individuals, households, and groups; and (3) the notion that the vulnerability context should be considered (see below) 
However, rather than focusing on vulnerability, our framework needs to give centre stage to barriers that have different effects on different types of actors.

Since we view adaptation to climate change as embedded in a broader set of livelihood processes, we turn to the sustainable livelihood approach (SLA) to start building our framework. SLA helps to capture the effect of climate change on people's livelihood strategy and to explore different factors that shape adaptation decisions and choices (Below et al. 2014).

SLA connects various livelihood elements, including 'assets (natural, physical, human, financial and social), the activities, and the access to these [...] that together determine the living gained by the individual or household' (Ellis 2000, p 10). A livelihood is more than merely the generation of income and also includes activities related to the gaining and retaining of access to resources and opportunities, dealing with risk, negotiating within the household and managing social networks and institutions within communities (Scoones 1998). People combine various resources (i.e. livelihood assets) to create livelihood strategies for survival and/or for improving their well-being. These resources are dynamic in nature, and access is mediated by social relations, institutions and organisations (Ellis 2000).

SLA pays attention to both resources and mediating factors. However, mediating factors are not always fully integrated in most studies (de Haan and Zoomers 2005). The overemphasis on assets rather than on mediating factors is considered as a reason for the lack of attention that gender seems to get in livelihood literatures (Krishna 2012). To address the gender gap, Krishna (2012) argues that gender concerns need to be brought more explicitly into SLA. Taking up this challenge, we attempt to give gender an explicit place in our framework. The framing of gender aspects in livelihood studies needs to go beyond categories and roles of men and women, and needs to allow for a deeper analysis that grasps the lived experiences of men and women as shaped by different social realities. Doing so requires the conceptualisation of gender as a constituent element of social structure and cultural interpretation (Scott 1986), and as an integral aspect of social processes (Acker 1992).

How can this notion be given a proper place in SLA? The premise of SLA is that mediating processes play a pivotal role in guiding livelihoods through influencing access, livelihood strategies, decision-making and interaction among different types of capital (Ellis 2000; Scoones 1998). According to Scoones (1998, p 12), mediating processes are 'Formal and informal organisations and institutions with regularised practices or patterns of behaviour that are structured by rules and norms of societies which have persistent use'.
As noted in gender literatures, these same formal and informal institutions and processes lead to the (re)production of gender inequality, both overtly and covertly (Lowndes and Roberts 2013). Therefore, gender must be conceived of as a central aspect of mediating processes. Attaining this necessitates an understanding of what are often called gendered institutions-a notion used to explain how gender relations and the construction of femininity and masculinity are entrenched in daily institutional processes and practices (Acker 1992; Lowndes and Roberts 2013). Building upon this notion, we propose to assign a central role to gendered institutions as a possible barrier to adaptation, which also directly or indirectly capture the effect of other types of barriers (e.g. financial and social barriers).

Lowndes and Roberts (2013) note different dimensions by which the gendered understanding of institutions can be captured: gendered rules, gendered effects of rules, gendered actors and gendered policy outcomes. For this study, we focus on gendered rules and gendered effects of rules. North (1990, p 3) defines institutions as 'the rules of the game'; hence, gendered rules are rules, norms and practices that affect, among others, the behaviour, activities, roles and relations of men and women, respectively, in differentiated ways. Gendered effects refer to the fact that the impact of institutions is differentiated along gender lines. For the purpose of this study, we propose to modify the SLA framework, taking into consideration these two aspects of gendered institutions (see Fig. 1).

In the framework, the first and core component regards gendered institutions as barriers to adaptation. This concept emphasises both formal and informal institutions, and as such also captures social, cultural, and governance barriers (IPCC 2014a). This component focuses on two analytical notions-gendered rules, norms and practices and gendered effects of rules, norms and practices. The framework recognises and allows for the analysis of gender at the individual, household and community levels (see also Behrman et al. 2014). However, since the household is the unit of analysis in this study, such issues are examined here primarily from the experiences at household levels.

Moreover, gendered institutions are perceived here as a possible barrier with a differentiated impact on access to the five livelihood capitals, i.e. the second core component of the framework. Natural capital comprises natural resource stocks including land, forest and rangeland. Physical capital encompasses access to roads, to communication such as radio and telephone, and to farming oxen and tools. Human capital covers the ability to labour (e.g. the presence of adult male household members) and access to skills training. Social capital consists of bonding, membership of (in)formal organisations and linking networks. Finally, financial capital includes income (from on- 


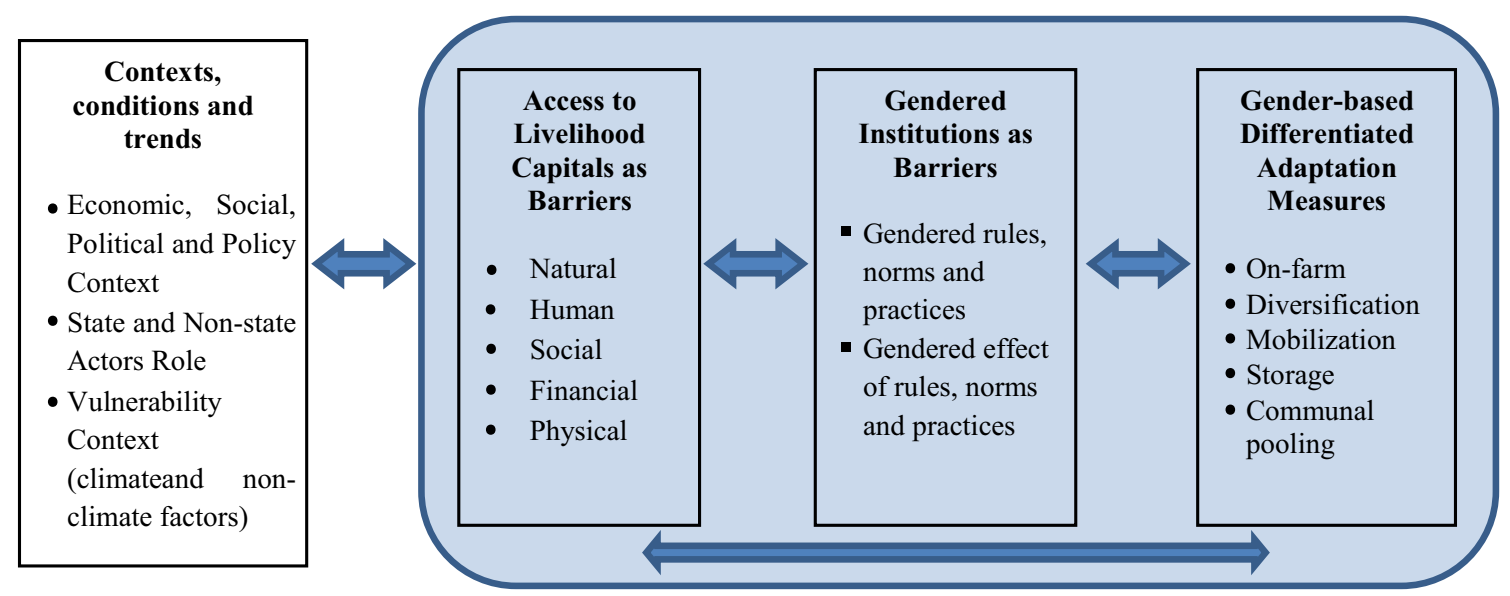

Fig. 1 Conceptual framework of the study. Source adopted from Scoones (1998)

and non-farm activities), access to credit and livestock ownership. The ways in which gendered institutions affect differentiated access to these capitals create additional barriers to adaptation.

The third core component of the framework regards adaptation measures. Adaptation measures in the modified framework are substitutes for livelihood strategies in the original framework. Adaptation measures refer to the range and combination of activities and choices that households make in order to achieve their goals. Our study uses Agrawal's (2010) activity-oriented analytical classification of adaptation measures, which focuses on activities that involve either the pooling or sharing of risks. After our fieldwork, we adapted Agrawal's classification to make it more suited to local circumstances. We recognise the following adaptation measures: on-farm adaptation, mobility, storage, off- and non-farm diversification, and communal pooling.

On-farm adaptation measures include change in cropping season, change in varieties of crops, mixed cropping (combining crops to reduce the risk of crop failure) and soil management. Mobility refers to the distribution of risk across spaces. For example, individuals may temporarily migrate to another area to engage in alternative income-generating activities. Storage, or, the distribution of risk across time, is another option. Storage becomes an effective method when there is a well-developed infrastructure, low levels of perishability and a high level of coordination across households and social groups (Agrawal 2010, p 19). Diversification refers to the pooling of risk across resources and livelihood activities, and includes the engagement in off-farm activities (Ellis 2000). Communal pooling is concerned with the distribution of risk across households; accordingly, in response to risk, vulnerable households pool their collective resources (Agrawal 2010).
In line with the original SLA framework, we also recognise the importance of context, traditions, and trends. Hence, the framework considers what we call the vulnerability context (see also Behrman et al. 2014) that includes both climate change-related factors (e.g. drought) and nonclimate factors (e.g. land degradation and poverty). It also draws attention to the possible influence of state and nonstate actors (e.g. NGOs and donors) and to socio-economic, political, and policy processes. The forward and backward linkages depicted in the visualisation of the framework denote the interaction between different components.

\section{The context: Ethiopia}

Located in the Horn of Africa, Ethiopia is a diverse country both socially (with more than 80 ethnic groups) and physically. The topographic variation results in diverse climate conditions with 30 agro-ecological zones defined by temperature and moisture regimes (MoA 2011). The Ethiopian economy largely depends on the agricultural sector dominated by smallholders' rain-fed agriculture that contributes $43 \%$ to the GDP and generates $90 \%$ of export revenues. It is also the main source of food and employment for $85 \%$ of the population (MoARD 2010). The overwhelming dependency of the country's economy on rain-fed agriculture, combined with persistent poverty, makes any change and variability in climate a major threat for the country in general, and for rural livelihoods and food security in particular (Alebachew 2011).

Drought, as characterised by the absence of rainfall or the late or too early onset of inadequate rain (Gebrehiwot et al. 2011), has been associated with Ethiopia for long time. However, in terms of frequency, magnitude and spatial coverage, drought has been more pronounced in recent decades (Alebachew 2011). Since the 1970s, 
drought has hit the country every 10 years, and this interval seems to have shortened to 2-3 years, recently. Also, studies indicate a trend of increasing temperatures (Gebrehiwot et al. 2011).

\section{Gender in Ethiopia}

As a patriarchal society, gender norms and rules are biased in favour of men in Ethiopia, although variations across space and ethnicities exist. Rural women, and specifically female household heads, are identified as the most disadvantaged groups in highland farming communities where gender disparity in access to and control over productive resources such as credit, extension services and land is dominant (Alebachew 2011; MoWA 2006). An increasing trend in the number of households headed by women has been observed, and a recent report shows that one-fifth of all households (22\%) are headed by women (CSA 2014). Therefore, we chose to operationalise gender impact by looking at the differences between male- and femaleheaded households, respectively. Overall, despite the recent attempt to affirm women's rights and gender equality through progressive laws and policies, such laws and policies often remain on paper and gender gaps still persist due to deep-rooted gender norms and implementation failure (MoWA 2006).

\section{Study areas: Raya Azebo and Kobo Districts}

This study was conducted in two selected districts in the north-eastern highlands of Ethiopia, namely Raya Azebo in the Tigray Regional State and Kobo in the Amhara Regional State (Fig. 2), considering persistent drought and subsequent interventions by the government (and international donors). According to the districts' extension workers, the study areas experienced localised drought from 2010 to 2013 (personal communication). Based on the above-mentioned criteria, two drought-prone Kebeles (lowest administrative unit) were chosen from the districts as study sites: Mechare Kebele in the Raya Azebo district, and Zoble (Kebele 010), in the Kobo district.

Mixed farming is predominantly practiced in both study areas. Sorghum is the main crop, followed by maize, pulse and teff. ${ }^{1}$ The districts receive bi-modal rainfalls; Belg, the small rain, occurs during March-April followed by $\mathrm{Me}$ her-the main rainy season during June-September. Belg is the most important rainy season because crops like sorghum are planted during this time. Belg rain is also crucial for pasture. Most big droughts in Ethiopia are associated with dry Belg (Viste et al. 2012).

$\overline{1}$ Teff is fine grain that is Ethiopia's traditional staple.

\section{Methods}

Our analysis is based on a qualitative, single case study design where we combine within-case spatial variation with temporal variation to gain insights into the adaptation experiences of male- and female-headed households, respectively. We used purposeful sampling to select two drought-prone districts from Northern Ethiopia and two Kebele's from within these districts, considering the presence of persistent drought and erratic nature of rainfall. In our sample selection strategy, we tried to keep control variables that regard ethnicity, occupation and other socio-economic indicators constant, to the extent that that was possible. In agreement with, for example, Gerring (2001) and Yin (2013), we assume that whereas external validity is obviously compromised by the relatively small-N character of our study, the in-depth exploration of the two communities (that can be assumed to represent a larger pool in the region) may inspire the formulation of innovative working hypotheses for future research.

Focus group discussants were selected with the help of local extension workers, using random sampling. Snowball sampling was used to select household heads for the semistructured interviews. After local extension workers had identified one male household head and one female household head, these respondents were asked to recommend other male and female household heads for further interviews.

Jost et al. (2015) warn against the conceptualisation of women as one homogeneously vulnerable group in the discourse related to gender and climate change. We recognise that there is a distinct difference between interand intra-household gender dynamics, respectively. With regard to gender differences within the household, for example, Bernier et al. (2015) show that whereas increasing awareness about climate change increases the likelihood that farmers will adopt climate-smart agricultural (CSA) practices, providing information on climate change and CSA options to the husband does not mean that this information will also get passed on to the wife (see also Tall et al. 2014; Twyman et al. 2014). In order not to render our analysis unnecessarily convoluted by taking in two expressions of gender dynamics that are to an important extent different and unrelated, we chose to focus on interhousehold gender dynamics. We operationalise gender effects by means of differentiating between male- and female-headed households, respectively (see also Bryan et al. 2013; Deressa et al. 2009; Nabikolo et al. 2012; Hassan and Nhemachena 2008; Tazeze et al. 2012).We suggest that future work continues to look at intra-household gender dynamics, as well. 


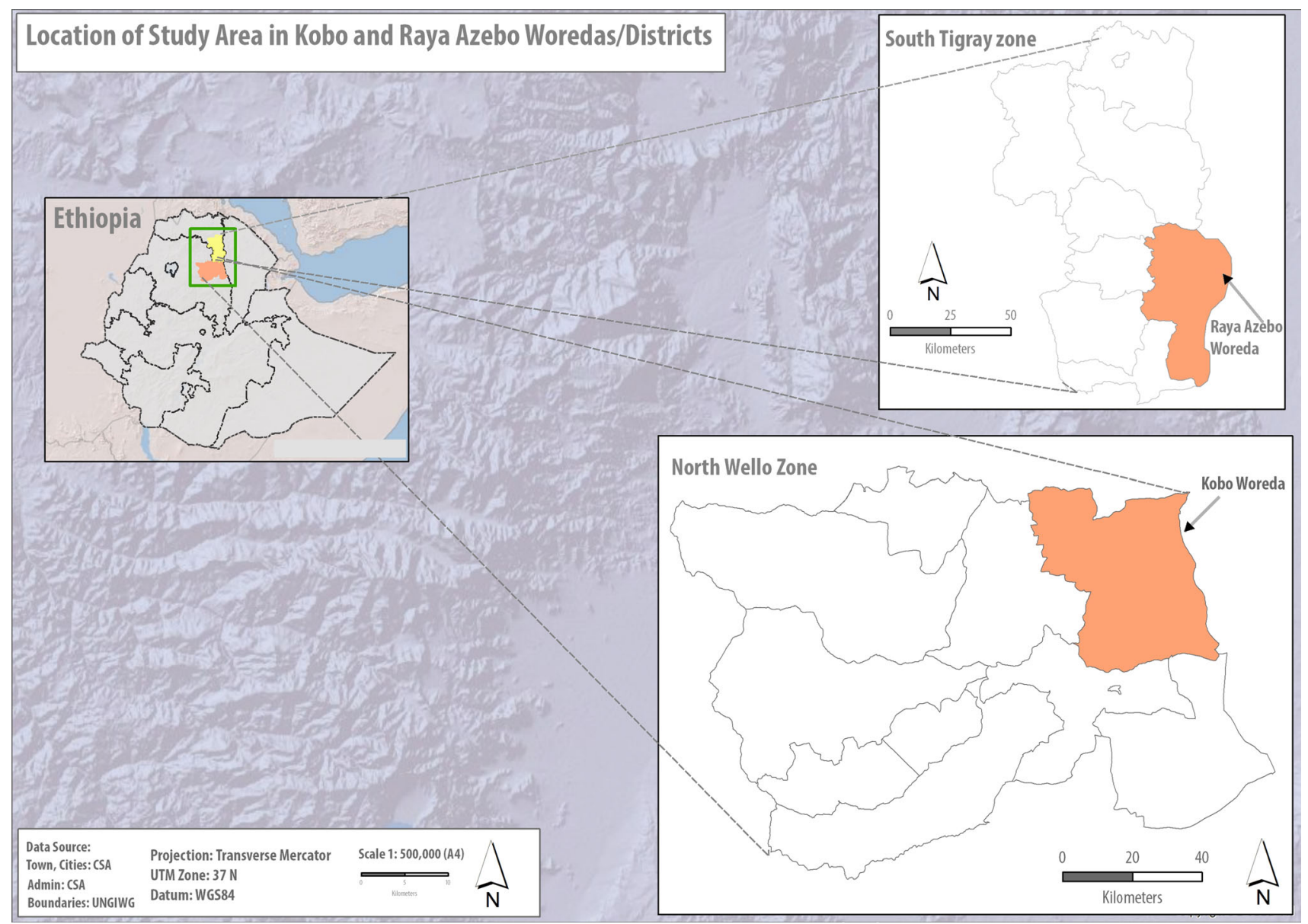

Fig. 2 Map of the study area

The empirical basis for this paper is fieldwork conducted in March 2014 and May 2014 using semi-structured interviews and focus groups discussion with male and female household heads. In addition, informal discussions with villagers, non-structured interviews with local extension workers and elderly villagers, and observations complemented the data collection.

Questions for the semi-structured interviews considered the conceptual framework-household asset portfolio, climate crisis/drought perception, adaptation measures and gendered institutions. First, indicators adopted from the literature were used to assess asset portfolios of households. However, interviews were flexible enough to capture locally emerging resources. Second, respondents were asked what 'change' they perceived in their locality and how such 'changes' relate to and affect their daily lives. When drought-related issues were referred to, more indepth explorations were carried out. Third, adaptation-related questions focused on what respondents did or do during droughts and what made them choose such measures. Fourth, questions linked with gendered institutional factors were addressed as a crosscutting issue while analysing the other three blocks. Moreover, these questions were being reconstructed throughout to probe deeper into newly emerging themes. This step coincides with the basics of grounded theory research (Charmaz 2006).

Mixed-sex focus group discussions in each study site, with 10 to 12 participants, were used as an entry point to data collection with the purpose of easing communication, grasping major issues and identifying potential interviewees. In total, 44 semi-structured interviews were conducted (23 in Zoble and 21 in Mechare). Twenty interviewees (10 in each area) were males, and 24 interviewees were female (11 in Mechare and 13 in Zoble). The age of interviewees ranged from 38 to 70 years. Female household heads consisted of widows (four), divorcees (15) and single women with children (four). At the end of the interviews, women-only focus group discussions were held in each study site to further uncover gender and women's experiences. Informal discussions with men were held while they had informal gatherings or were on their farm duties. With women, informal discussions were carried out when they participated in public work and during their informal gathering for coffee ceremonies. To facilitate the 
communication and arrange appointments, one female and one male field assistant, who work in the area as local extension and community health workers, were engaged. Most interviews were audio recorded, transcribed and coded. The data analysis was grounded in narrative analysis. 'Narrative analysis permits a holistic approach to discourse that preserves context and particularity' (Smith 2000, p 327).

\section{Result}

\section{The vulnerability context: the local perception of drought and its effects}

Perception about climate change and its effects influence whether actors decide to adapt. Similar to studies conducted in different parts of Ethiopia (Alebachew 2011; Deressa et al. 2009) and in other African countries (AntwiAgyei et al. 2014; Below et al. 2014), which find that farmers have clear ideas about changing trends in climate, the respondents of this study also reported change and variability in their local climate. Respondents described drought as a decline in and inconsistence of rainfall. Often, older respondents referred to the 1980s Sahel drought as a reference point for illustrating recurrent drought and the erratic nature of rainfall.

The perceived change in rainfall fluctuation is also evidenced in our meteorological data analysis drawn from two local meteorological stations. Both sites experienced increased variability of rainfall in the main (meher) and short (belg) rainy seasons during the last 30 years. Mainly during the belg, rainfall was below average in 16 out of 30 years.

Although respondents indicated non-climate factors such as soil degradation and shortage of farmland as having a negative impact on their livelihood, drought-induced problems emerged as vital. All respondents identified crop failure and grazing land damage as the main problems affecting their area. In Mechare, respondents also reported water scarcity for domestic usage and livestock: it caused women and girls to have to travel $2-3 \mathrm{~h}$ to fetch water. Traditionally, the community used a rainwater harvesting system (called Horeye). However, due to insufficient rainfall, it is currently impossible to collect enough water for the dry season. In addition, livestock diseases were mentioned by 16 men $(n=20)$ and five women $(n=23)$ in both areas, and malaria by five men $(n=10)$ and six women $(n=12)$ in Mechare, as problems that have intensified because of drought.

Households mentioned the effects of drought such as food shortage, death of livestock, over-reliance on government food aid and out-migration of young people.
Women particularly mentioned the erosion of social values and relations. This was elucidated by a participant of the women's focus group as 'when the sky stops giving rain, people also stop being kind and supportive'.

\section{Variation in adaptation measures taken by households}

Overall, the result indicates gender-based difference in choices of adaptation measures in both sites. On-farm adaptation measures, such as cropping time adjustment, crop diversification, planting cash crops (such as $K h a t^{2}$ and buckthorn) and soil conservation, were reported as important adaptation measures, especially by male household heads.

My parents and grandparents were farmers and so am

I. I am not an urban man. So I prefer to do whatever is

related with my farm. (Male Interviewee, Mechare)

As this quote indicates, male household heads preferred this adaptation measure not only in order to overcome drought but also to also to emphasise their strong bond with farming. In contrast, on-farm adaptation measures were not widely mentioned by female household heads.

Diversification (off-farm and non-farm) by participating in public work in exchange for (in kind or cash) 'aid' was the dominant adaptation measure mentioned by poor male household heads and almost all female household heads. Other, individual forms of diversification, such as petty trade, hairdressing, selling of local drinks, spices, firewood and charcoal, and working as a daily labourer, were widely used by female household heads. Some male household heads mentioned carpentry work and selling of charcoals and firewood.

Both internal and international migrations-adaptation related to mobility - were reported by households. Male household heads are more mobile and have less domestic responsibilities, and can therefore rely on income from temporary labour migration to nearby towns and large agriculture sites (such as Humera near the border with Sudan) during bad harvest times. However, their mobility highly depends on their age and health status. Although female household heads considered temporary mobility as a useful measure, they did not employ it, as they are responsible for caring for the children. A second form of mobility encountered relates to international migration, mainly to Gulf countries. Both focus group discussants and interviewees reported a growing trend in this form of

\footnotetext{
${ }^{2}$ Khat is a green-leaved tree, and people chew the leaves as a stimulant.
} 
migration among young people. ${ }^{3}$ Although acknowledging the important value of remittances, both men and women stressed the risks associated with the journey to and the stay in said destination areas, and the risks related to the impact of the absence of young people on the future of their community.

Most respondents reported that the recurrent nature of drought makes it impossible to use the storage of grain as an adaptation measure. Many households simply do not have surpluses that they can store away. Still, some betteroff male household heads mentioned that they sometimes store grains in order to sell surpluses at a profit when the price is at its highest.

Regarding communal pooling, both men and women stress the importance of their social networks and relatives during drought periods for borrowing money and grains. We observe that especially female-headed households and poor male-headed households often rely heavily on these networks. Sending out their children (above age nine or 10) to relatives in urban areas or to better-off neighbours to reduce household consumption was also reported by households. Table 1 provides an overview of our observations regarding variation in adaptation measures taken by households.

\section{Barriers to adaptation}

Gendered institutions create barriers to adaptation both directly and through influencing access to livelihood capitals. Firstly, gendered rules, norms and practices and gendered effects of rules, norms and practices create direct barriers to the development of adaptation measures. Secondly, the effect of gendered institutions on access may lead to the emergence of additional barriers, such as financial and economic barriers (related to the lack of access to financial capital), barriers related to the lack of human resources, knowledge and awareness (related to the lack of access to human capital), and barriers related to technology (related to the lack of access to physical capital; IPCC 2014a). Varying access to capitals, and the resulting barriers, affects the form and extent of the development and deployment of adaptive measures. In this section, we illustrate (1) what gendered rules, norms and practices, and the effects thereof, can be and (2) how their effect on access to livelihood capitals may lead to additional barriers.

\footnotetext{
3 The fieldwork time coincided with the deportation of more than 150,000 Ethiopian domestic workers by the Government of Saudi Arabia that gave us the opportunity to discuss with four youth returnees.
}

Table 1 Households' adaptation measures

\begin{tabular}{lll}
\hline Adaptation strategies & $\begin{array}{l}\text { Female- } \\
\text { headed } \\
\text { households } \\
(n=23)\end{array}$ & $\begin{array}{l}\text { Male- } \\
\text { headed } \\
\text { households } \\
(n=20)\end{array}$ \\
\hline On-farm adaptation & & \\
Cropping time adjustment & 3 & 20 \\
Mixed cropping & - & 20 \\
Planting commercial tree & 4 & 4 \\
Soil conservation & 6 & 20 \\
Mobility & - & 14 \\
Temporary migration & 13 & 8 \\
International migration & & 10 \\
Diversification & 23 & 3 \\
Labour-intensive public work & 23 & 13 \\
Individual-based diversity & & 11 \\
Storage & 2 & 4 \\
Grain storage & & \\
Communal pooling & 23 & \\
Borrowing money from neighbours & 23 & \\
Sending out children & 14 &
\end{tabular}

Sources field data

\section{Gendered institutions as barriers to adaptation}

Gendered Rules, Norms and Practices: Gender-Based Division of Labour In both study areas, the division of labour between women and men follows strict and rigid gender norms and conceptions that define farming knowledge and skills (productive activities) as the men's domain and reproductive activities and the domestic sphere as women's territory. In the local language, the word 'farmer' is, by default, associated with 'he'. There exists a taboo against women ploughing, regardless of their land ownership status. This gendered restriction on women ploughing is justified by referring to 'honour' and women's physical ability.

Women are soft and honoured; pushing soil and working in dirt is not their place. Rather, being in the mud and tilling his land is what makes a man a real man. (Male interviewee in Mechare)

Ploughing is not a challenging job for women. Our sons at the age of 13 ploughed. We know we can do it but cannot summon the courage to face critics. (Female interviewee in Zoble)

Since we were never given the chance to do it, I think it is hard to say whether women are able or not. However, for sure, we don't have the skill. We were trained to be good at domestic activities but not at ploughing. We need to know how to farm first. (Female interviewee in Mechare) 
The first narrative is an indication of rural femininity and masculinity to justify what is deemed appropriate to women and men. The restriction is a very deeply rooted norm in the community; even during interviews, the question 'why not' clearly irritated male interviewees and elders. Restrictive norms make farming a masculine domain. Thus, on-farm adaptation measures become the most commonly used and preferred measures for men. At the same time, these norms create barriers for women household heads, disallowing them to implement the same type of measures.

Share-cropping Due to restrictive norms against women's ploughing, most women rent their land for sharecropping. It is a rental arrangement bound by traditional rules that define responsibilities, the crop sharing ratio and the management of farming costs. In negotiations, women have no voice, nor bargaining power to agree upon farm utilisation and harvest sharing. In Mechare, female landowners pay for land tax and fertilisers, whereas the (male) tenant performs all farming activities, and decides on crop type and farm utilisation. After the harvest, the landowner gets one-third (siso) of the harvest and the tenant takes two-thirds, plus all of the residuals, such as chaff. In Zoble, attributed to farmland shortage, the share taken by the landowners improved gradually from onequarter to one-third and nowadays, half. Moreover, tenants have started paying for fertilisers and land tax. But the tenant still decides on crop type and farm utilisation. Interviewed women expressed their concerns regarding the unfairness of the deals and the mismanagement of their farm.

Sometimes, if the tenant doesn't fear God, he deliberately leaves the margin of my farm uncultivated so that he can use it to graze his cattle (Female interviewee in Zoble)

Thus, the power imbalance in sharecropping arrangements makes on-farm adaptation almost unattainable for women household heads since the right to decide on types of crop, timing and farming management is taken away from them. On the contrary, it creates an opportunity for men in the community to rent land, diversify their adaptation measures, and get additional income.

Gendered Effects of Rules, Norms and Practices From interviews and focus group discussions, we learned that adaptation measures in both areas are highly influenced by extension services and government aid packages.

Extension services include training, technical support on farmland management, and the provision of farming inputs and livestock health services. Male respondents report the positive role of extension services, especially related to onfarm adaptation. However, since agriculture extension workers often contact male farmers, the majority of women do not link extension services with their adaptation measures. The only extension service linked with rural women is training (see Table 2); however, the themes of the training showed gender differences. Training for women focuses on their reproductive and community roles (child nutrition, sanitation and hygiene, family planning and compost and biogas), not on developing their farming skill, which reinforces local gendered norms and the division of labour.

Through Ethiopia's Productive Safety Net Programme (PSNP), participants get compensation (either in kind or in cash) in return for their engagement in public work (e.g. helping to build infrastructures for public use). PSNP focuses on chronically food-insecure households and particularly singles out women-headed households as the main targets. The impetus of the public work is to create a nonfarm means of (income) diversification. Indeed, studied households acknowledge the important role of the programme, especially during times of drought. Nevertheless, critically evaluated from a gender perspective, the problematic aspect of PSNP is the assumption that all farmers engage in on-farm activities. However, as described earlier, women do not take part in farming activities due to genderbased restrictions. Thus, for women household heads, the PSNP packages provide a substitute for and not an addition to farm activities.

\section{Gendered livelihood capitals as barriers}

Tangible resources include natural, physical and financial assets. Access to natural assets-i.e. farmland, forest and grazing land-is controlled by the government as all land is owned and administered by the state in Ethiopia. We therefore did not come across distinct gender-based differences in terms of access to land. This finding corresponds with the findings of Kumar and Quisumbing (2015).

Villagers can only get access to forest based on schedules issued by local government officials. No significant access distinction was found between male- and femaleheaded households. Regarding grazing land, only ploughing oxen are allowed to use it. Other livestock uses cut grazing (in Zoble) or grazing along the village border (in Mechare). Interviewees highlighted that the shrinking of grazing land has caused a reduction in livestock and a shift from mixed farming to predominantly crop production.

All studied households have the user rights to farmland ${ }^{4}$ with varying fertility and size. Four female-headed

\footnotetext{
${ }^{4}$ However, this should not be taken as general fact for all rural women in Ethiopia. This finding is most possibly caused for two reasons: first, the research is carried out in Northern Ethiopia where women historically have relatively better access to land (Kumar and Quisumbing (2015)), and second, the majority of the respondents are older.
} 
Table 2 Household's asset portfolios

\begin{tabular}{|c|c|c|}
\hline Resources & Female-headed households $(n=24)$ & Male-headed households $(n=20)$ \\
\hline \multicolumn{3}{|l|}{ Natural capital } \\
\hline Access to farm land & All own farmland & All own farmland \\
\hline Forest & Limited access & Limited access \\
\hline Access to range land & No households use rangeland & 14 households use range land (only for their oxen) \\
\hline \multicolumn{3}{|l|}{ Physical capital } \\
\hline Road access & All have access to roads & All have access to roads \\
\hline $\begin{array}{l}\text { Communication (radio } \\
\text { and mobile phone) }\end{array}$ & 2 households own a radio; 3 households own a mobile phone & $\begin{array}{l}9 \text { households own a radio; } 8 \text { households own a } \\
\text { mobile phone }\end{array}$ \\
\hline Farming oxen and tools & No households owns oxen; no household owns farming tools & $\begin{array}{l}9 \text { households own } 2 \text { oxen; } 5 \text { households own } 1 \text { ox; } \\
\text { All households own farming tools }\end{array}$ \\
\hline \multicolumn{3}{|l|}{ Financial capital } \\
\hline Farm income & $\begin{array}{l}18 \text { households got half to one-third of their harvested yield; } 5 \\
\text { households keep their full harvested yield }\end{array}$ & All households keep their full harvested yield \\
\hline Non-farm income & $\begin{array}{l}\text { All households receive income from public work. } \\
\text { All households receive income from other non-farm activities }\end{array}$ & $\begin{array}{l}10 \text { households receive income from public work } \\
2 \text { households receive income from other non-farm } \\
\text { activities } \\
13 \text { households receive income from temporary } \\
\text { migration }\end{array}$ \\
\hline Access to credit (formal) & 13 households & 15 households \\
\hline Livestock ownership & $\begin{array}{l}5 \text { households own sheep and/or goat (ranging from } 2 \text { to } 7 \\
\text { animals) } \\
2 \text { households own a cow } \\
4 \text { households own a donkey }\end{array}$ & $\begin{array}{l}14 \text { households own sheep and goat (ranging from } 4 \\
\text { to } 20 \text { animals) } \\
9 \text { households own cows (ranging from one to three } \\
\text { heads) } \\
11 \text { households own camels and/or donkeys }\end{array}$ \\
\hline \multicolumn{3}{|l|}{ Human capital } \\
\hline Literacy & No households & 5 households \\
\hline Farming ability & 4 households & All households \\
\hline Training & 19 households & All households \\
\hline \multicolumn{3}{|l|}{ Social capital } \\
\hline \multicolumn{3}{|c|}{ Participation in membership/bonding } \\
\hline $\begin{array}{l}\text { Iddir/Kire (funeral } \\
\text { association) }\end{array}$ & 23 households & 20 households \\
\hline $\begin{array}{l}\text { Ikub (traditional saving } \\
\text { association) }\end{array}$ & 20 households & 12 households \\
\hline $\begin{array}{l}\text { Peasant association } \\
\text { (government based) }\end{array}$ & 6 households & 11 households \\
\hline $\begin{array}{l}\text { Women's association } \\
\text { (government based) }\end{array}$ & 21 households & 16 households \\
\hline \multicolumn{3}{|c|}{ Participation in linking/bridging } \\
\hline $\begin{array}{l}\text { Farming labour } \\
\text { exchange system }\end{array}$ & 5 households & 20 households \\
\hline
\end{tabular}

households and two male-headed households inherited the land-use rights from their parents. The remaining respondents acquired user rights to their land during the 1991 nationwide reallocation of land, following the change in government. The land holdings of male household heads, as they include the spouse's entitlements, are larger than the plots held by female household heads. Respondents mentioned small farm sizes and the decline of soil fertility as constraints to on-farm adaptation.

In relation to physical resources, both study areas have access to roads between the district town and the villages, and public transport is available. Respondents felt that radiocommunication is not so relevant in their daily activities since the weather and market information 
disseminated by this means is not tailored to specific local conditions. Farming is predominantly carried out by traditional ploughs pulled by two oxen; consequently, ownership of ploughing oxen emerges as the most relevant physical asset in both areas. Farmers with only one ox negotiate with another farmer in the same situation to farm their respective land, in turn (an arrangement called Mekenajo). But, farmers with no oxen either rent oxen for 1 day in exchange for 2 days of farm labour for the oxen owner or rely on the traditional labour exchange system. As depicted in Table 2, none of the women-headed households own oxen. Only those households with adult male members can farm their land in either of the above-mentioned ways. Respondents reported that the ownership of ploughing oxen plays a crucial role, especially in relation to adaptation to drought. As the rain becomes inconsistent and erratic, timely farm preparation and rainwater use becomes increasingly important. Poor farmers with one or no oxen are disproportionately affected.

With regard to financial assets, we observed that the farm income of most female-headed households significantly differs from male-headed households. Often, female-headed households can keep only half or one-third of their harvest because of a sharecropping arrangement (see Table 2). Participation in labour-intensive public work was the main source of non-farm income $(<1 \$$ US per day for 8-h service) for all female-headed households and half the male-headed households. Male-headed households owned relatively more livestock than female-headed households.

Intangible resources such as human and social capital also influence decisions regarding adaptation measures. Human capital-especially the actual ability to farmemerges as a gendered and critical barrier for femaleheaded households. In both areas, gendered norms prohibit women from ploughing; consequently, only three femaleheaded households (see Table 2)who live with their adult sons farm their land themselves. The rest rely on social networks or rent their land out for sharecropping. This is also why most female-headed households did not mention any on-farm adaptation strategy. Instead, they focus on diversification.

With specific regard to social capital, traditional funeral associations (Idir/Kire) are important. Villagers support each other at a time of the loss of a family member, but also of household's assets, e.g. caused by the unexpected death of livestock. As depicted in Table 2, all male-headed households take part in the local reciprocal labour support system (called 'Ofera' in Mechare and 'Jigie' in Zoble). This system plays a key role in rural livelihoods. People who cannot farm themselves, such as the elderly, women, and farmers without oxen, rely on this system. When asked for support, neighbours bring their own oxen and farming tools to plough, and in return, the caller provides food and drinks for lunch and contributes his/her labour when others require help. Male household heads report that this system helps them to pursue farming regardless of their deprivation in physical capital (i.e. lack of ploughing oxen) and to employ on-farm adaptation. However, for female household heads, it was not an option as illustrated by the following narrative.

Five years ago, I called 'Ofera' [ask for support] of about 30 male farmers and prepared food and drink by borrowing money. Finally, only three men showed up and I wasted my money in vain. Since then, I used sharecropping. (Female household head in Mechare)

To clarify the reason why men did not show up when women called them, a question was raised during the informal discussions with men. All agreed on the growing erosion of social support, and one of the discussants mentioned that:

The hardship in life caused by insufficient rain, land degradation and low agricultural productivity negatively affects our social values. Now, everybody wants to spend more time on their farm or on other income-generating activities rather than on helping others. (Male informal discussant in Mechare)

However, female-headed households with adult sons or male relatives may manage to be part of the support system.

It was impossible for me to organise 'Jigie' [labour exchange] before; however, for the last three years, it has become easy since my son already started farming. Now, everyone shows up when we call them because they know that he will help them in return' (Female household Head in Zoble)

As the quotes indicate, the success of organising such support entirely depends on the caller's ability to offer return labour and on the financial ability to prepare food and drink. Table 2 provides an overview of the observed variation in households' assets portfolios.

\section{Discussion and conclusion}

Adaptation to climate change is a dynamic and inherently complex process influenced by both climate and non-climate factors (Adger et al. 2009). Among various factors that influence adaptation processes, heterogeneity within a given community results in significant differences in the employment of adaptation measures. Gender-based differences-i.e. differences in ascribed roles and responsibilities and differences in access to resources and power- 
shape men's and women's adaptation processes and possibilities differently (Djoudi and Brockhaus 2011). The findings of our study confirm this claim. More particularly, we find that whereas diversification is the dominant adaptation measure reported by female-headed households, male-headed households engage in a much more diverse set of adaptation measures - they have a wider range of choices, including on-farm adaptation (which was also the preferred one), temporary migration, storage, communal pooling and diversification.

Our analysis shows how the complex ways in which different and connected barriers impact adaptation demand an understanding that goes beyond the outcomes alone. The gender-based divergence in adaptation measures is neither a matter of preference, nor of differences in perceptions between male and female household heads on the extent and problematic nature of droughts, but an outcome of gendered barriers to adaptation. Gendered institutions create barriers to adaptation through rules, norms and practices (such as division of labour, sharecropping and gender-neutral approaches) and through generating more access barriers for women than for men. All in all, barriers to adaptation influence the adaptation process of households in a differentiated manner-i.e. due to gender norms and practices, female- and male-headed households encounter and experience barriers to adaptation in different ways. For instance, social barriers (e.g. the reciprocal labour exchange system) may very well facilitate the adaptation process of male-headed households (especially for poor households), whereas they may simultaneously hinder the adaptation processes of female-headed households. Despite farmland ownership, the restrictive norms against women's ploughing (informal institutional barrier), the de facto exclusion from participating in the reciprocal labour support system (social barrier) and their lower bargaining power in establishing sharecropping arrangements (institutional barrier) intertwine to eventually result in a low financial capacity (financial barriers) of femaleheaded households. As a result, storage adaptation measures become unfeasible for them.

The broader implication of our study touches upon the conceptual and theoretical debate regarding adaptation processes. Conceptually, as indicated in earlier work (Adger et al. 2009; Biesbroek et al. 2013), adaptation processes and barriers to adaptation strongly link with both climate and non-climate factors. We believe that using SLA enabled us to capture the dynamics between climate and non-climate factors and to deal with adaptation decisions as part of people's livelihood path. In adjusting and applying the SLA framework, we aimed at providing empirical evidence as to how gender can be meaningfully addressed from a livelihoods' perspective. Our gendersensitive version of the SLA framework helped to trace how gendered institutions create linkages among various barriers to adaptation and finally constrain the adaptation choices of female-headed households.

Theoretically, we notice a growing interest in barriers to adaptation and strategies to overcome these. The findings of our study add new insights to the debate. The first notion is that despite the understanding of barriers as having an overall negative impact on adaptation (Biesbroek et al. 2013), we clearly show them to have a differentiated impact upon different actors. Recognising this will enable the design of strategies to effectively overcome barriers to adaptation without compromising their facilitating role. The second notion relates to the connection among barriers to adaptation. As illustrated in our study, different barriers interact with each other and result in a distinctive outcome for actors who are at the junction point of such interactions.

A practical implication of our findings is that (planned) interventions to overcome barriers to adaptation-by governments, donors and NGOs-should be inclusive of all actors. Failure to take cognisance of the interconnectedness among barriers to adaptation may lead to discriminatory outcomes where often-disadvantaged groups such as female-headed households will end up having even more limited adaptation options, rendering them even more vulnerable to climate change.

Acknowledgments The research for this article is funded by the NICHE/ETH/020 Project, administered by Tilburg University, and the authors are grateful for the support. We would like to thank Peter Driessen for his valuable comment on earlier drafts of the article. The authors also want to thank all research respondents for their participation as well as the anonymous reviewers.

Open Access This article is distributed under the terms of the Creative Commons Attribution 4.0 International License (http://crea tivecommons.org/licenses/by/4.0/), which permits unrestricted use, distribution, and reproduction in any medium, provided you give appropriate credit to the original author(s) and the source, provide a link to the Creative Commons license, and indicate if changes were made.

\section{References}

Acker J (1992) From sex roles to gendered institutions. Contemp Sociol 21(5):565-569

Adger WN, Arnell NW, Tompkins EL (2005) Successful adaptation to climate change across scale. Glob Environ Change 15:77-86. doi:10.1016/j.gloenvcha.2004.12.005

Adger WN, Agrawala S, Mirza MMQ, Conde C, O’Brien KL, Puhlin J, Pulwary R, Smit B, Takahasi K (2007) Assessment of adaptation practices, options, constraints and capacity. Climate change 2007: impacts, adaptation and vulnerability. In: Parry ML, Canziani OF, Palutikof JP, van der Linden PJ, Hanson CE (eds) Contribution of working group II to the fourth assessment report of the intergovernmental panel on climate change. Cambridge University Press, Cambridge, pp 717-743 
Adger WN, Dessai S, Goulden M, Julme M, Lorenzoni I, Nelson DR, Naess LO, Wolf J, Wreford A (2009) Are there social limits to adaptation to climate change? Clim Change 93:335-354. doi:10. $1007 / \mathrm{s} 10584-008-9520-\mathrm{z}$

Agrawal A (2010) Local institutions and adaptation to climate change. In: Mearns R, Norton A (eds) Social dimension of climate change and vulnerability in a warming world. The World Bank, Washington, DC, pp 173-197

Alebachew A (2011) Climate change and rural livelihoods in Northern Ethiopia. Impacts, local adaptation strategies and implications for institutional interventions. FSS Monograph No. 7. Forum for Social Studies, Addis Ababa

Antwi-Agyei P, Stringer LC, Dougill AJ (2014) Livelihood adaptations to climate variability: insights from farming households in Ghana. Reg Environ Change 14(4):1615-1626. doi:10.1007/ s10113-014-0597-9

Behrman JA, Bryan E, Goh A (2014) Gender, climate change, and group based approaches to adaptation. In: Ringler C, Quisumbing AR, Bryan E, Meinzen-Dick R (eds) Enhancing women's assets to manage risk under climate change. Potential for groupbased approaches. IFPRI, Washington, DC, pp 3-8

Below RB, Julia CS, Sieber S (2014) Farmers' knowledge and perception of climate risk and options for climate change adaptation: a case from two Tanzanian villages. Reg Environ Change 15(7):1169-1180. doi:10.1007/s10113-014-0620-1

Bernier Q, Meinzen-Dick R, Kristjanson P, Haglund E, Kovarik C, Bryan E, Ringler C, Sivestri S (2015) Gender and institutional aspects of climate-smart agricultural practices: evidence from Kenya. CGIAR Research Program on Climate Change. Agriculture and Food Security (CCAFS), Copenhagen

Biesbroek GR, Klostermann JEM, Termeer CJAM, Kabat P (2013) On the nature of barriers to climate change adaptation. Reg Environ Change 13(5):1119-1129. doi:10.1007/s10113-013-0421-y

Bretherton C (1998) Global environmental politics: putting gender on the agenda? Rev Int Stud 24(1):85-100

Bryan E, Ringler C, Okoba B, Roncoli C, Silvestri S, Herrero M (2013) Adapting agriculture to climate change in Kenya: household strategies and determinants. J Environ Manag 114:26-35. doi:10.1016/j.jenvman.2012.10.036

Charmaz K (2006) Constructing grounded theory: a practical guide through qualitative analysis. Sage, London

CSA (Central Statistical Agency) (2014) Ethiopia Mini Demographic and Health Survey 2014. Ethiopia Central Statistical Agency, Addis Ababa

De Haan L, Zoomers A (2005) Exploring the frontier of livelihoods research. Dev Change 36(1):27-47. doi:10.1111/j.0012-155X. 2005.00401.x

Deressa TT, Hassan RM, Ringler C, Alemu T, Yesuf M (2009) Determinants of farmers' choice of adaptation methods to climate change in the Nile Basin of Ethiopia. Glob Environ Change 19(2):248-255. doi:10.1016/j.gloenvcha.2009.01.002

Djoudi H, Brockhaus M (2011) Is adaptation to climate change gender neutral? Lesson from communities dependent on livestock and forest in northern Mali. Int For Rev 13(2):123-135. doi:10.1505/146554811797406606

Ellis F (2000) Rural livelihoods and diversity in developing countries. Oxford University Press, Oxford

Gebrehiwot T, Veen A, Maathuis B (2011) Spatial and temporal assessment of drought in the Northern highlands of Ethiopia International. J Appl Obs Geoinf 13(3):309-321. doi:10.1016/j. jag.2010.12.002

Gerring J (2001) Social science methodology: a criterial framework. Cambridge University Press, New York

Hassan R, Nhemachena C (2008) Determinants of African farmers' strategies for adapting to climate change: multinomial choice analysis. Afr J Agric Resour Econ 2(1):83-104
IPCC (2014a) Climate Change 2014: Impacts, Adaptation, and Vulnerability. Part A: Global and Sectoral Aspects. Contribution of Working Group II to the Fifth Assessment Report of the Intergovernmental Panel on Climate Change. Cambridge University Press, Cambridge and New York, p 1132

IPCC (2014b) Annex II: Glossary In: Climate Change 2014: Impacts, Adaptation, and Vulnerability. Contribution of Working Group II to the Fifth Assessment Report of the Intergovernmental Panel on Climate Change. Cambridge University Press, Cambridge and New York, pp 1757-1776

Jost C, Kyazze F, Naab J, Neelormi S, Kinyangi J, Zougmore R, Aggarwal P, Bhatta G, Chaudhury M, Tapio-Bistrom ML, Nelson S, Kristjanson P (2015) Understanding gender dimensions of agriculture and climate change in smallholder farming communities. Clim Dev. doi:10.1080/17565529.2015.1050978

Krishna S (2012) Redefining sustainable livelihood. In: Harcourt W (ed) Women reclaiming sustainable livelihood: space lost, space gain. Palgrave, London, pp 12-20

Kumar N, Quisumbing AR (2015) Policy reform toward gender equality in Ethiopia: little by little the egg begins to walk. World Dev 67:406-423. doi:10.1016/j.worlddev.2014.10.029

Lowndes V, Roberts M (2013) Why institutions matter. Palgrave, Basingstoke

MacGregor S (2010) Gender and climate change: from impacts to discourse. J Indian Ocean Rev 6(2):223-238

MoA (Ministry of Agriculture) (2011) Agriculture sector programme of plan on adaptation to climate change. Federal Democratic Republic of Ethiopia, Addis Ababa

MoARD (Ministry of Agriculture and Rural Development) (2010) Ethiopia's agricultural sector policy and investment framework (PIF) 2010-2020. Draft Final Report, Addis Ababa

MoWA (Ministry of Women's Affairs) (2006) National action plan for gender equality (NAP-GE), 2006-2010, Addis Ababa

Nabikolo D, Bashaasha B, Mangheni MN, Majaliwa JGM (2012) Determinants of climate change adaptation among male and female headed farm households in eastern Uganda. Afr Crop Sci J 20(2):203-212

North DC (1990) Institutions, institutional change and economic performance. Cambridge University Press, Cambridge

Scoones I (1998) Sustainable rural livelihoods: a framework for analysis. IDS working paper, 72. IDS, Brighton

Scott JW (1986) Gender: a useful category of historical analysis. Am Hist Rev 91:1053-1075

Smith CP (2000) Content analysis and narrative analysis. In: Reis H, Judd C (eds) Handbook of research methods in social and personal psychology. Cambridge University Press, Cambridge, pp 313-335

Tall A, Kristjanson P, Chaudhury M, KcKune S, Zougmore R (2014) Who gets the information? Gender, power and equity considerations in the design of climate services for farmers. CGIAR Research Program on Climate Change, Agriculture and Food Security (CCAFS), Copenhagen

Tazeze A, Haji J, Ketema M (2012) Climate change adaptation strategies of smallholder farmers: the case of Babilie district, East Harerghe zone of Oromia regional state of Ethiopia. J Econ Sustain Dev 3(14):1-12

Twyman J, Green M, Bernier Q, Kristjanson P, Russo S, Tall A, Ampaire E, Nyasimi M, Mango J, McKune S, Mwongera C, Ndourba Y (2014) Adaptation actions in Africa: evidence that gender matters. CGIAR Research Program on Climate Change, Agriculture and Food Security (CCAFS), Copenhagen

Viste E, Korecha D, Sorteberg A (2012) Recent drought and precipitation tendencies in Ethiopia. Theor Appl Climatol 112(3):535-551. doi:10.1007/s00704-012-0746-3

Yin RK (2013) Case study research: design and methods. Sage Publications, Los Angeles 